\title{
Functional Diversity of Morphologically Similar Digestive Organs in Muroidea Species
}

\author{
E. I. Naumova ${ }^{a}$ *, T. Yu. Chistova ${ }^{a}$, A. A. Varshavskii ${ }^{a}$, and G. K. Zharova ${ }^{a}$ \\ a Severtsov Institute of Ecology and Evolution, Russian Academy of Sciences, Moscow, 119071 Russia \\ *e-mail:einaumova@gmail.com \\ Received December 10, 2019; revised March 20, 2020; accepted March 20, 2020
}

\begin{abstract}
We examine possible ways of functional adjustment of morphologically similar alimentary tracts in rodents with different dietary specializations. We study the structure of stomach and gut epithelial surface as well as the features of its colonization with microorganisms in five gerbil species: Psammomys obesus, Meriones crassus, Gerbillus henleyi, G. andersoni, and $G$. dasyurus. Data on the morphological diversity of mucosaassociated microbiota have been obtained and confirmed by the results of previous microbiology studies. Species differences in chymus acidity associated with dietary specialization have been determined. Variations in the activity of the endoglucanase microbial enzyme, which is crucial for rodents fed on cellulose-containing food, have also been detected. The importance of microbiota for functional adaptations to various food types in rodents with morphologically similar digestive tracts has been evaluated.
\end{abstract}

DOI: $10.1134 / \mathrm{S} 1062359021020084$

\section{INTRODUCTION}

A semiglandular stomach is a mandatory attribute of the digestive tract of all muroid rodents (Muroidea), regardless of their dietary specialization. Cornification of a part of the gastric epithelium in rodents results from the evolutionary interaction of animals with microorganisms obligatory for the digestion of plant food. The morphology of the semiglandular stomach is extremely diverse and is usually associated with the role of cellulose-containing food in the diet of rodents (Vorontsov, 1967, 1982). Voles (Microtinae), highly adapted to herbivory, have a bilocular stomach; the nonglandular part of it is isolated into a separate chamber, and the glands either occupy the entire right half of the stomach or are concentrated in the central part (discoglandular stomach). However, sometimes voles do not show an obvious association between the structure of the stomach and intestines and food specialization. For example, Microtus arvalis and Ellobius talpinus with the discoglandular stomachs consume food with different fiber contents (Naumova, 1981; Naumova et al., 2018).

Dietary specialization of the other group of rodents, gerbils of the family Gerbillidae, also did not significantly affect the morphology of the stomach and intestines (Behmann, 1973; Naumova, 1981; Snipes, 1982; Naumova et al., 2011). All gerbils are characterized by a single-chamber semiglandular stomach and a cecum with the same structure of the ileocecal junction. The main morphological features that ensure the adaptation of individual species of the group to certain food include the size of the intestinal parts (Naumova et al., 2011). Despite the fact that gerbils are similar to voles in the range of dietary specialization, although they live in environmental conditions of limited food resources, high temperature, and moisture deficit, functional aspects for their food adaptations have not yet been disclosed. It is obvious that it is impossible to decipher the adaptation of animals to changing environments using only morphoecological approaches. An understanding of the functional role of the intestinal microbiota in different aspects of the host's life has emerged only in the past two decades due to the use of microbiological, biochemical, and other research methods (Kohl et al., 2011; Kohl and Carey, 2016).

The aim of this work is to specify the functional features of the microbiota that ensure the assimilation of different types of food with the example of gerbils, a group of rodents with a homogeneous structure of the digestive tract and different food specialization.

\section{MATERIALS AND METHODS}

Five gerbilline species inhabiting the Negev Desert have been studied: Psammomys obesus, Meriones crassus, Gerbillus henleyi, G. andersoni, and G. dasyurus (2-4 individuals of each species). These rodents are classified as granivorous (Bar et al., 1984), with the exception of $P$. obesus, which consume exclusively green parts of plants (Daly and Daly, 1975). On a JSM $840 \AA$ scanning electron microscope (Japan), the macro- and microrelief of the surface of the mucous 
membrane of the forestomach, cecum, and colon were studied. Tissue samples were washed with isotonic sucrose solution and fixed with 3\% glutaraldehyde. After treatment with alcohols and acetone, the samples were dried in air and sprayed with gold. The acidity of the gastric content was determined with a universal indicator paper at the apex of the fundus, in the nonglandular part of the stomach near the border fold, in the area of the fundus glands, and in the pylorus, as well as in the cecum body.

The activity of the microbial enzyme endoglucanase was measured in P. obesus, M. crassus, G. andersoni, and $G$. dasyurus by a viscosimetric method (Sinitsyn et al., 1990). The use of this method in studies of the activity of enzymes of the cellulase complex allows us to compare the results obtained with previously published data. Samples of the chyme from the forestomach, cecum, and colon were transferred in preweighed Eppendorf tubes containing $1 \mathrm{~mL}$ of $86 \%$ glycerol (in total, nine individuals were examined); the sample weight was determined by repeated weighing. The analysis of the results of endoglucanase activity determination was carried out in the software environment R (R Core Team, 2019) using the RKWard graphical interface (Friedrichsmeier, 2018). For primary data processing, both basic and additional $\mathrm{R}$ packages were used: dplyr (Wickham et al., 2019) and tidyr (Wickham and Henry, 2019) for primary data processing; ggplot2 (Wickham, 2016) for graph creation; and also original designed functions.

\section{RESULTS \\ Epithelial Surface and Associated Microbial Communities}

The surface of the keratinizing epithelium of the forestomach of gerbils forms folds of various sizes. The large ones change their configuration due to peristalsis and smooth out as the stomachs fill. Small folds, formed by the surface layers of the epithelium, are constantly present and create a fine mesh relief (Fig. 1), which can change due to the desquamation of superficial epithelial cells. Such an architectonics of the epithelial surface of the forestomach is typical for all the gerbil species studied.

The forestomach of rodents, as well as the cecum and colon, are abundantly populated with symbionts, some of which are attached to the epithelial surface in order to avoid washing out by the contents passing through the digestive tract. A review of studies on normal microbiota of rodents (carried out mainly on mice and rats), maintained on commercial pelleted foods, showed that its composition was ubiquitous (Tannock, 1997). According to the available data, in the muroid species studied the proximal parts of the digestive tract are usually dominated by lactobacilli with a developed mechanism of attachment to the keratinizing epithelium. The distal parts are dominated by various repre- sentatives of the genera Enterococcus and by Escherichia coli. Although detailed studies of the microbiota in various species of wild rodents have rarely been carried out, there is reason to believe that many muroid species have a specific microbiota (Perrin and Kokkinn, 1985; Naumova, 1990). A visual examination on a scanning electron microscope of the associations of bacteria colonizing the epithelium of the digestive tract of gerbils showed their great diversity even just in morphological features.

In $P$. obesus, the epithelium-associated microbiota of the forestomach is represented mainly by bacilli and fusiform bacteria. Bacilli 1-2 $\mu \mathrm{m}$ long are present in all gerbils studied, but most abundantly they colonize the epithelium in $M$. crassus and $G$. henleyi. In the forestomach microbiome associated with the epithelium, corynemorphic bacteria were recorded in $G$. andersoni and cocci, in $G$. dasyurus. In general, in all gerbils, epithelium-associated bacilli predominate in the forestomach.

There are open crypts on the surface of the mucous membrane of the cecum (Fig. 2); the mucous membrane around the crypt openings forms concentric folds. In all gerbils the microbiota of the cecum mucous membrane is represented mainly by fusiform bacteria and cocci, while filamentous bacteria are found in $G$. andersoni. In the colon, the highest density of bacteria is observed on the surface of the mucous membrane of the mesenteric wall; on the oblique folds, bacteria are concentrated in the crypt openings (Fig. 3). In P. obesus, the colon microbiota is more diverse in comparison to those in the forestomach and cecum. In this species, large (4-5 $\mu \mathrm{m})$ bacilli and curved rod-shaped bacteria predominate in the colon; in M. crassus, fusiform bacteria and cocci do. In three species of the genera Gerbillus, the mucous membrane is colonized by the most shape-diverse bacteria; in $G$. andersoni and $M$. crassus, very large $(>19 \mu \mathrm{m})$ rod-shaped bacteria are also found.

\section{Acidity of the Stomach and Cecum Content}

The fundus is characterized by a close to neutral $\mathrm{pH}$ in the herbivorous and largest gerbil $P$. obesus. This $\mathrm{pH}$ is maintained relatively uniformly throughout the forestomach, slightly increasing near the border with the glandular part. In the zone of the fundus glands, acidity rises sharply and reaches a maximum ( $\mathrm{pH} 1.0)$ in the antral part, providing a very high gradient (Table 1). In other species, the forestomach is characterized by a weakly acidic $\mathrm{pH}$ level ( $\mathrm{pH}$ 4.0-5.0), but high acidity is also maintained in the antral part. Only in the small granivorous $G$. henleyi is there no dramatic change in acidity from the fundus to the antrum, as well as a sharp border that creates different environmental conditions in the forestomach and the glandular part of the stomach. The zone of the fundus glands and the antrum in all species is characterized by high acidity $(\mathrm{pH} 1.0-2.0)$. In the cecum the $\mathrm{pH}$ is very stable and 

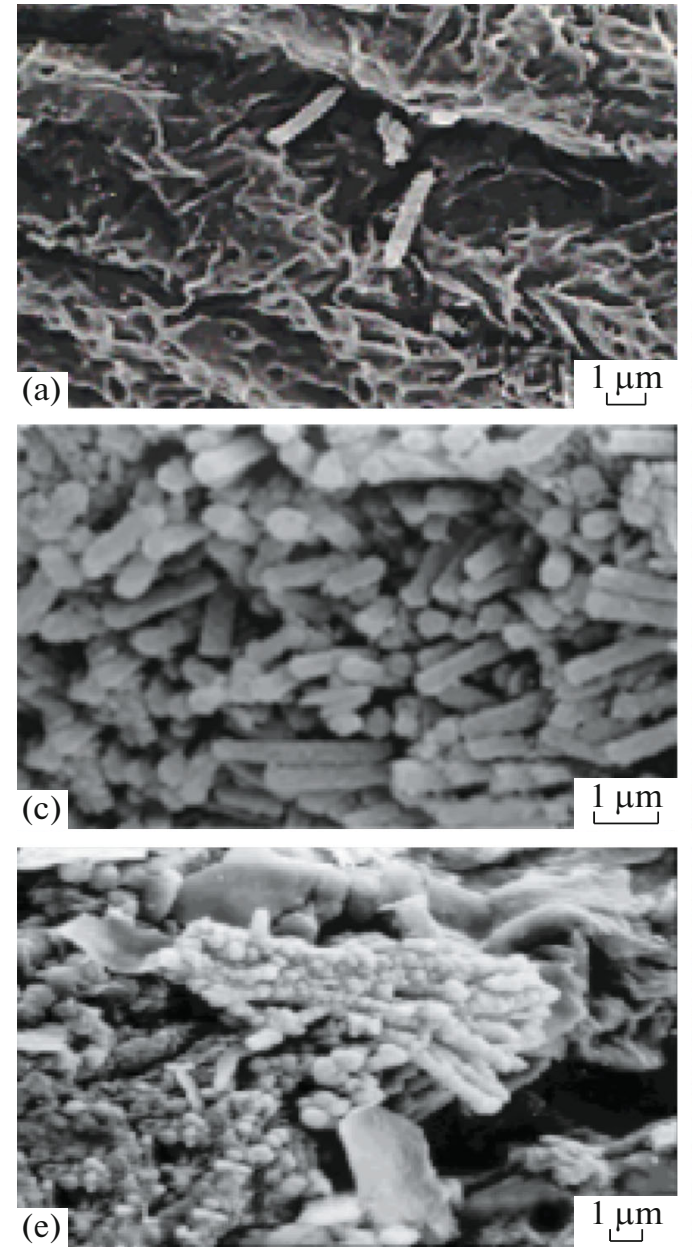

Fig 1. Forestomach epithelium of the gerbils. $(\mathrm{a}, \mathrm{b})$ P obesus; $(\mathrm{c})$ Figs. 1 and 3.

is slightly alkaline in all gerbils studied. Only $G$. henleyi has a lower $\mathrm{pH}$ in the cecum.

\section{Endoglucanases}

Endoglucanase activity (EA) characterizes the hydrolysis of amorphous $\beta$-glucans, topographically associated with fibers, and makes these fibers available for further hydrolysis. The diagram (Fig. 4) presents the EA values of microsymbionts inhabiting the forestomach, cecum, and colon in four gerbil species and, for comparison, similar data for two species of Microtus sp. obtained on large samples (Varshavskii et al., 2004). As the sample size was quite small, the averaged data allows us to compare results only at the order level of values. Nevertheless, some general characteristics of EA in voles and gerbils can be noted. In the forestomach of all the species studied, except for G. dasyurus, EA values were $0.85-2.15 \mu \mathrm{mol} / \mathrm{min}$, which is close to the average values for the Microtus voles. The absence of EA in the forestomach is common for all the species studied. EA values in the cecum vary from 1.07 to
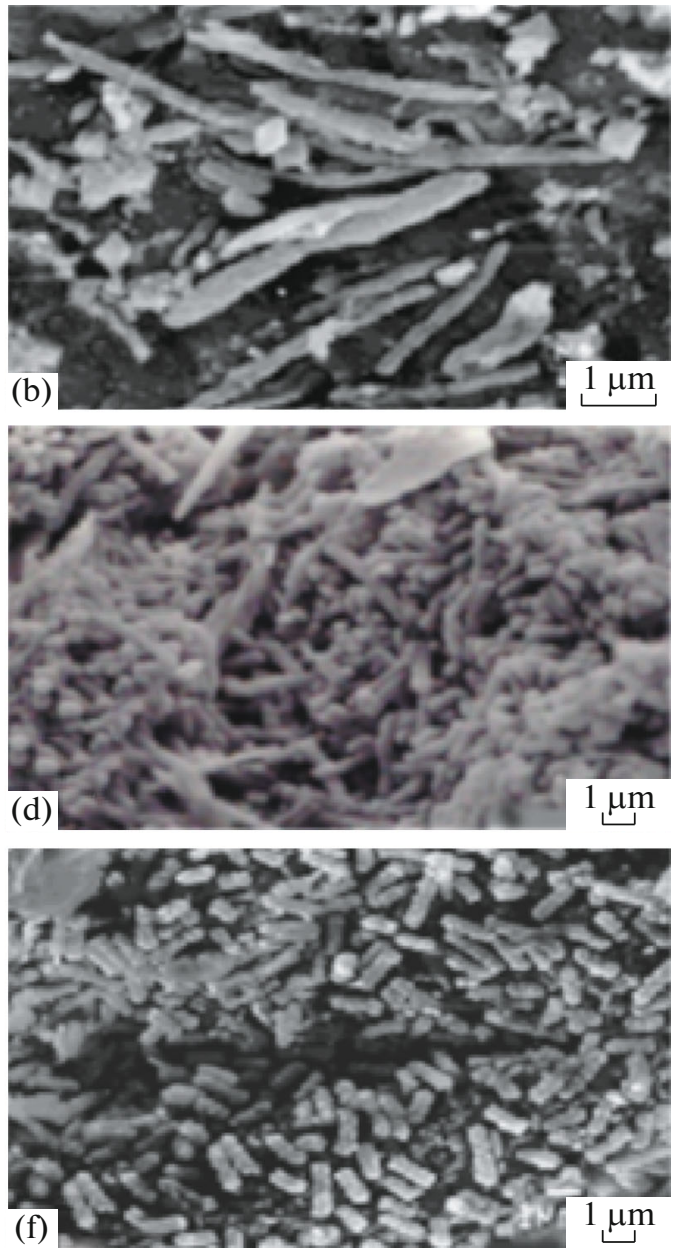

(c) M. crassus; (d) G. dasyurus; (e) G. andersoni; (f) G. henleyi; for 

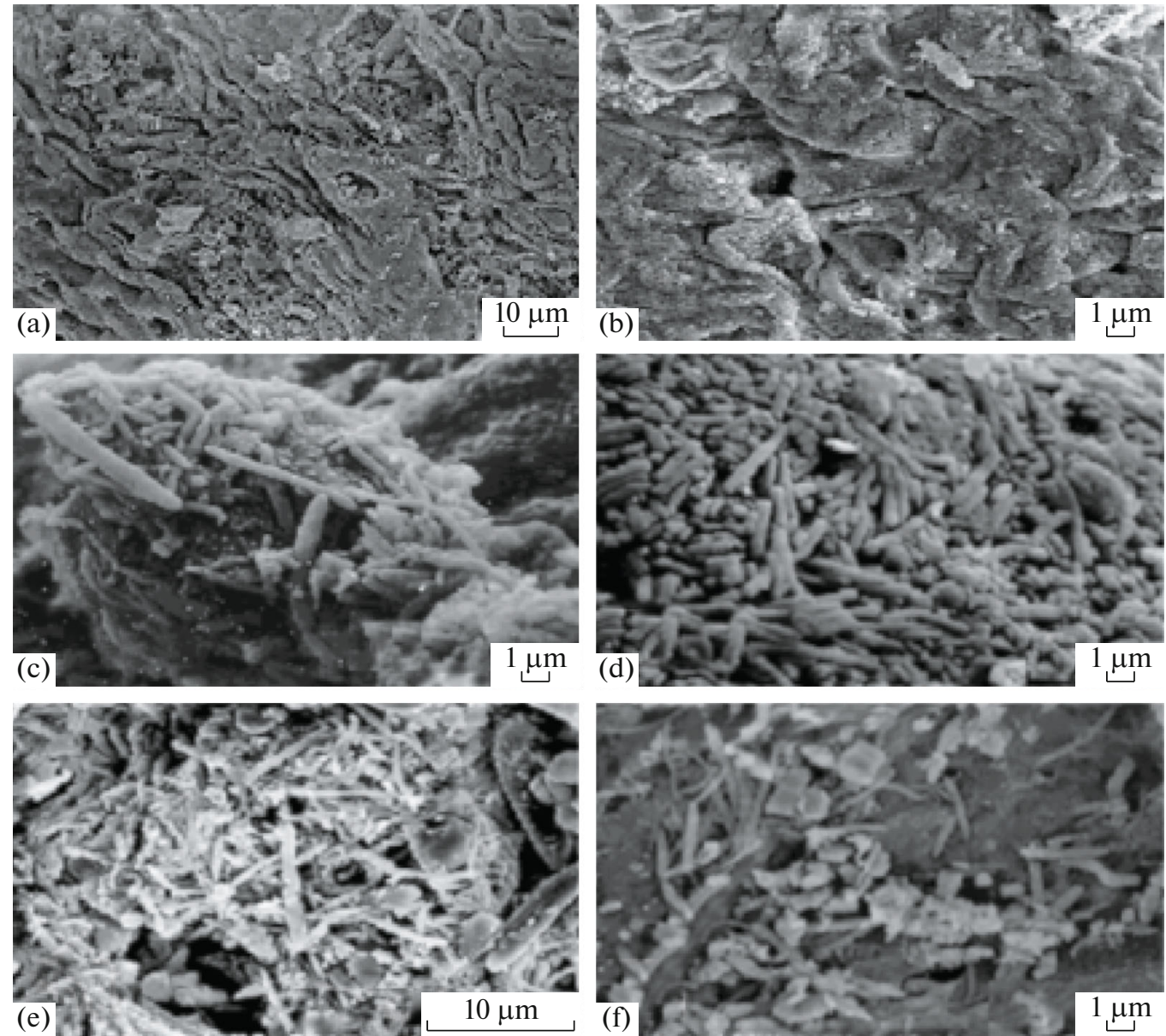

Fig. 2. Cecum epithelium of the gerbils. (a) P. obesus; (b, c) M. crassus; (d) G. dasyurus; (e) G. andersoni; (f) G. henleyi.

which are tolerant to structural carbohydrates in plants (Daly and Daly, 1973; Fedorova and Dubrovskii, 1987; Degen et al., 2000). The development of digestive organs in this group of rodents was associated with the exploitation of the poor plant food reserves in deserts and semi-deserts under conditions of water restriction. The single-chamber semiglandular stomach, typical for gerbils, was considered less adapted for

Table 1. Acidity of the stomach and cecum contents in gerbils $(\mathrm{pH})$

\begin{tabular}{|c|c|c|c|c|c|c|}
\hline \multirow[b]{2}{*}{ Species } & \multirow[b]{2}{*}{$n$} & \multicolumn{4}{|c|}{ Stomach } & \multirow[b]{2}{*}{ Cecum } \\
\hline & & fundus & border zone & $\begin{array}{l}\text { fundus gland } \\
\text { zone }\end{array}$ & antrum & \\
\hline P. obesus & 4 & $\begin{array}{c}5.88 \\
(5.0-7.0)\end{array}$ & $\begin{array}{c}5.00 \\
(4.0-6.0)\end{array}$ & $\begin{array}{l}1.00 \\
(1.0)\end{array}$ & $\begin{array}{l}1.00 \\
(1.0)\end{array}$ & $\begin{array}{l}7.00 \\
(7.0)\end{array}$ \\
\hline M. crassus & 4 & $\begin{array}{c}4.75 \\
(4.0-5.0)\end{array}$ & $\begin{array}{c}4.25 \\
(4.0-5.0)\end{array}$ & $\begin{array}{c}1.50 \\
(1.0-3.0)\end{array}$ & $\begin{array}{c}1.50 \\
(1.0-3.0)\end{array}$ & $\begin{array}{l}7.00 \\
(7.0)\end{array}$ \\
\hline G. dasyurus & 3 & $\begin{array}{c}4.33 \\
(4.0-5.0)\end{array}$ & $\begin{array}{c}4.50 \\
(4.0-5.0)\end{array}$ & $\begin{array}{c}1.83 \\
(1.0-2.5)\end{array}$ & $\begin{array}{l}1.00 \\
(1.0)\end{array}$ & $\begin{array}{l}7.00 \\
(7.0)\end{array}$ \\
\hline G. andersoni & 2 & $\begin{array}{l}5.00 \\
(5.0)\end{array}$ & $\begin{array}{l}5.00 \\
(5.0)\end{array}$ & $\begin{array}{c}1.50 \\
(1.0-2.0)\end{array}$ & $\begin{array}{r}1.00 \\
(1.0)\end{array}$ & $\begin{array}{l}7.00 \\
(7.0)\end{array}$ \\
\hline G. henleyi & 2 & $\begin{array}{l}4.00 \\
(4.0)\end{array}$ & - & $\begin{array}{l}3.00 \\
(3.0)\end{array}$ & $\begin{array}{c}1.50 \\
(1.0-2.0)\end{array}$ & $\begin{array}{c}6.25 \\
(6.0-6.5)\end{array}$ \\
\hline
\end{tabular}

$n$ is the number of animals. 

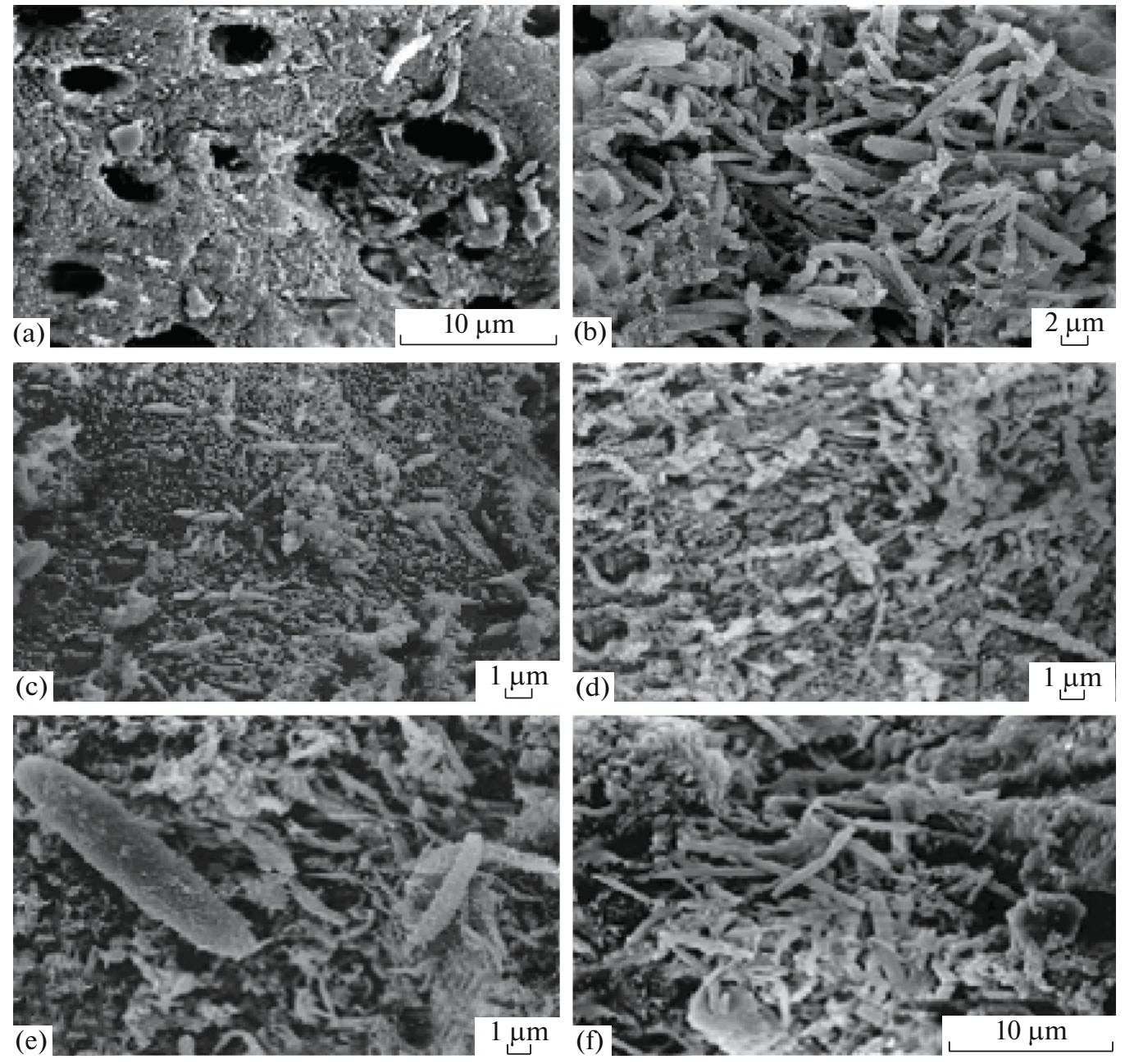

Fig. 3. Epithelium of the colon of the gerbils.

the fiber forage assimilation in comparison to the bilocular stomach of the voles. The increase in the area of the keratinizing epithelium in the single-chamber stomach was considered for a long time as an adaptation to the increasing role of cellulose feed in the diet of rodents. However, a survey of a large number of stomachs of gerbils showed that the ratio of the areas of the glandular and keratinized epithelium is quite variable and largely depends on the nature of the filling of the stomach and the distribution of the food mass in it. In gerbils, adaptations to the forage with differ chemical compositions and nutritional value are realized not only by optimizing the size of the intestinal parts responsible for the assimilation of concentrated or fiber feed, but also due to the specific functioning of microbial communities and endogenous secretions.

One of the main indicators influencing the structure of microbial communities is the quality composition of the food. Thus, dietary changes in laboratory mice significantly alter the microbial diversity (Carmody et al., 2015). Up to $64 \%$ of the innate microbiota species was preserved in the wild rodents after being transferred to captivity (Kohl and Dearing, 2014). More than that, the composition of microbial communities is largely determined by the colonization of the digestive tract by transit bacteria associated with the plants consumed (Kuznetsova at al., 2013). A similar relationship between the microbiota and characteristics of the food consumed is confirmed by the visualization of the morphological diversity of epithelium-associated bacteria in the gerbils and the enzymatic activity of microbial communities.

\section{Composition of Microbial Communities}

Mammals, depending on their food specialization, are hosts for microbial communities of different taxonomic composition and functions (Ley et al., 2008; Muegge et al., 2011). The keratinizing epithelium of the forestomach and the mucous membrane of the large intestine form an optimal microrelief for bacterial colonization. Microcells of the forestomach epithelium and oblique folds of the Kerckring relief prevent bacteria from being washed out during the move- 


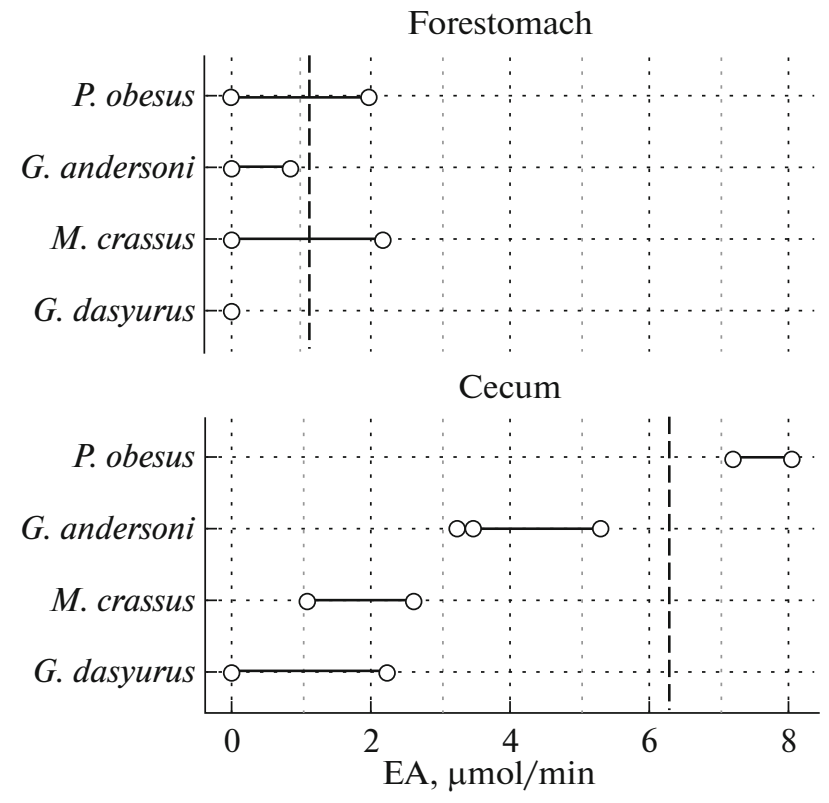

Fig. 4. Endoglucanase activity in the forestomach and cecum of gerbils $P$. obesus, $G$. andersoni, $M$. crassus, and $G$. dasyurus. The vertical dashed line shows the median EA values of Microtus sp.

ment of the contents. The morphological diversity of the microbiota of the stomach and intestines demonstrated in gerbils was also confirmed by microbiological studies (Kuznetsova et al., 2013). Representatives of the genera Bacillus, Arthrobacter, and other corynemorphic bacteria, cellulolytic bacteria of the genera Myxobacterales, Staphylococcus, Micrococcus, Bacteroides, and Aquaspirillum were isolated from various organs of the gerbils' digestive tract. All these bacteria were isolated as dominant members of the communities, while Lactobacillus, representatives of the family Enterobacteriacea, genus Bifidobacterium, and some others made up $1 \%$ of all microorganisms found in the digestive tract of gerbils. B. megaterium and Bacteroides spp. are common inhabitants of the digestive tract of animals (Naumova et al., 2005).

In previous studies, it was found that gerbil species differ in the quantitative ratio of the representatives of different bacterial genera detected (Kuznetsova et al., 2013). In M. crassus, the number of representatives of the order Myxobacterales in the forestomach and colon was quite high; in all parts of the gastrointestinal tract examined, a large number of gram-negative bacteria of the genus Aquaspirillum were found. Staphylococcus and Micrococcus have also been found in the forestomach, cecum, and colon of M. crassus. Perhaps one of the reasons for the poor colonization of the forestomach epithelium in P. obesus is the localization of cellulolytic bacteria in the organ cavity directly on the substrate. A similar low level of bacterial colonization was observed in the stomach of the herbivorous $R$. opymus (Naumova, 1999). This fact could be con- sidered as an important mechanism of adaptation to the food composition. The differences in the microbiota composition in phytophagous mammals of different taxa were also found using molecular genetic methods (Kohl et al., 2011). Microbial communities of the digestive tract are also known as a natural buffer for digestion under conditions of seasonal fluctuations in the quality of forage plants (Fon and Nsachlai, 2012). Specific relationships between hosts and their microbial communities can be formed during seasonal changes in the environmental conditions (Carey and Duddleston, 2014).

\section{Acidity}

Microbial colonization can be influenced not only by the nutrient composition and physical properties of the contents of the digestive tract and oxygen availability, but also by the $\mathrm{pH}$ level. The acidity of the gut content in rodents largely depends on the structure of the stomach (Kohl et al., 2013). The bilocular stomach of voles better than the single-chambered one provides a contrasting $\mathrm{pH}$ gradient, which is necessary to create different digestive conditions, alloenzymatic and symbiotic. A noticeable acidity gradient was noted for the herbivorous Microtus brandtii with a bilocular stomach (Naumova and Zharova, 1984). However, in the single-chambered semiglandular stomach in gerbils, a significant acidity gradient also can be created; in the largest gerbil $P$. obesus it amount to $7 \mathrm{pH}$ units. The high acidity gradient in gerbils results from the dividing role of borderline and angular folds (Naumova et al., 2011), as well as the upper position of the forestomach relative to the glandular part in a living animal. The acidity gradient in small Gerbillus is not as sharp as in larger species due to the lesser morphological differentiation of the stomach.

The different $\mathrm{pH}$ levels in the forestomach of different gerbils ensure the fermentation of various plant substrates. In particular, a $\mathrm{pH}$ of $6-7$, noted in the forestomach content of $P$. obesus, is optimal for glycan fermentation; at $\mathrm{pH} 4-5$, the initial hydrolysis of the protein takes place. The differences in the morphology of bacteria colonizing the nonglandular epithelium and the different levels of EA correspond to these facts.

\section{Enzymes}

Structural carbohydrates are found in greater or lesser amounts in any plant food. In the digestive tract of most herbivorous mammals, a complex of symbiotic microorganisms has evolved. It is capable of hydrolyzing fiber to simple bioavailable sugars. The increased interest in the study of EA is explained by the high content of amorphous $\beta$-glucans in plant food (Rabinovich et al., 2001) and their availability for bacterial degradation, which makes them an easily digestible nutrient for the host. Bacteria decompose cellulose with the help of high-molecular-weight 
extracellular structures called cellulosomes (Rabinovich and Melnik, 2000). Cellulosomes can be considered as molecular complexes consisting of many different enzymes that decompose ordered forms of cellulose and endoglucanase, which hydrolyzes glucan chains of cellular fibrils (Tokuda et al., 2005). Our results illustrate the high lability of the cellulase enzyme systems associated with the nutritional and metabolic characteristics of the hosts. Thus, in the diet of granivorous small gerbils, glycans are not an important nutrient, which corresponds to the low EA in representatives of the genera Meriones and Gerbillus, in contrast to P. obesus, in the cecum of which the EA is comparable to that in herbivorous voles.

The high morphological diversity of epitheliumassociated bacteria of the digestive tract suggests the possibility of bacterial synthesis of a wide range of enzymes essential for the host. The microbiocenosis of the gerbils' digestive tract is important not only for the carbohydrate diet of gerbils. One of the main recently elucidated functions of microbial communities in the digestive tract of rodents was nitrogen fixation (Naumova et al., 2000; Kuznetsova et al., 2010, 2013). Nitrogenase producers of different taxa were found in several species of murid rodents, including three species of gerbils with different dietary specialization. Until now, the role of nitrogen-fixing microorganisms in providing the host with nitrogen has not been fully elucidated, but their participation in maintaining the nitrogen balance in the biosphere is obvious.

The digestive tract is abundantly populated by urealytic prokaryote symbionts, which hydrolyze urea. In the predominantly granivorous Meriones meridianus, the urease activity in all parts of the digestive tract was significantly higher than in herbivorous Microtus socialis (Stepankov et al., 2018). The functioning of urealytic microorganisms can provide a significant contribution to the water balance of animals by reducing the loss of water during urine excretion. In an arid climate, nitrogen recyclization reduces the mass of excreted urea and, consequently, the mass of excreted water (Brosh et al., 1987; Freudenberger and Hume, 1993).

Herbivorous gerbils of the deserts cover their water requirements by feeding on plant foliage (Degen, 1997; Degen et al., 1997) and having a sufficiently capacious cecum. Small granivorous species obtain water by oxidizing high-calorie nutrients, during which urea is released, which serves as a substrate for urealytic bacteria.

\section{Adaptive Role of Microbiota}

The absence of vivid specific features in the gut structure of gerbils is largely covered by the functional specificity of microsymbionts. Although gerbils' microbiota functions are not well understood, it is clear that the accumulation of a microbial mass in the stomach and intestines reduces the animal's requirements for dietary protein. The complex architectonics of the mucous membrane surface of the cecum and colon increases the efficiency of absorption of microorganism metabolites and water. According to the constitution of the colon mucosa, this gut part, like in other Muroidea, has a high separator activity, especially in P. obesus (Naumova et al., 2019). This function reduces the loss of microbial protein by the host due to the accumulation of microorganisms between the oblique folds of the mucous membrane, which prevents them from being washed out.

In phytophagous mammals interactions with microorganisms play an important role in the life of the hosts. The microbiota participates in the synthesis of microbial protein, which increases the nutritional value of food, which can occur both by nitrogen fixation (Naumova et al., 2000; Kuznetsova et al., 2010) and by urea recycling (Kennedy and Hume, 1978; Vecherskii et al., 2015). The most important function of microorganisms is the use of structural carbohydrates as a nutrient, which is confirmed by the data on the digestibility of cellulose-containing food by $P$. obesus, the most active consumer of the green parts of desert plants. This indicator in P. obesus is somewhat lower than in other herbivorous rodents (Batzli and Cole, 1979; Hammond and Wunder, 1991; Foley and Cork, 1992; Justice and Smith, 1992; Degen et al., 2000). In addition to nutrients, the succulent green parts of plants contain sufficient moisture to maintain life in arid conditions. Water deficit in the habitats of gerbils is one of the most important factors that affect the structural and functional specifics of the gerbils' digestive tract.

Structural transformations of the digestive tract of two widespread groups of small mammals (gerbils and voles) associated with the consumption of plant food have both similarities and differences. The similarities lay in formation of the nonglandular part of the stomach, the ileocecal junction, which partially isolates the cavity of the cecum, and the separator mechanism of the colon, which is the most important regulator of the movements of various food fractions. Against the background of this similarity, the less pronounced structure of the gerbils' digestive tract in comparison to the voles' makes it possible to consider gerbils as a generalized group of phytophagous rodents to a lesser extent than voles specializing in feeding on cellulosecontaining food. Gerbils, which do not have clearly expressed species-specific differences in the structure of the digestive tract, use their own microbiota to adapt to the peculiarities of the food supply in arid regions, characterized by instability of vegetation and fruiting of food plants and, which is especially important, to water deficit (Degen, 1997). Therefore, physiological adaptations to the seasonal changes in the food quality and water retention in the body play an important role in formation of their nutrition and 
digestion strategy. These adaptations are carried out through symbiosis with microorganisms.

\section{ACKNOWLEDGMENTS}

We are grateful to A. Degen, M. Kam, I.S. Khokhlova, and B.R. Krasnov for the material provided and organization of the work.

\section{COMPLIANCE WITH ETHICAL STANDARDS}

Conflict of interest. The authors declare that they have no conflict of interest.

Statement on the welfare of animals. All applicable international, national, and/or institutional guidelines for the care and use of animals were followed.

\section{OPEN ACCESS}

This article is licensed under a Creative Commons Attribution 4.0 International License, which permits use, sharing, adaptation, distribution and reproduction in any medium or format, as long as you give appropriate credit to the original author(s) and the source, provide a link to the Creative Commons licence, and indicate if changes were made. The images or other third party material in this article are included in the article's Creative Commons licence, unless indicated otherwise in a credit line to the material. If material is not included in the article's Creative Commons licence and your intended use is not permitted by statutory regulation or exceeds the permitted use, you will need to obtain permission directly from the copyright holder. To view a copy of this licence, visit http://creativecommons.org/licenses/by/4.0/.

\section{REFERENCES}

Abramsky, Z., Communities of gerbilline rodents in sand dunes of Israel, in Patterns in the Structure of Mammalian Communities, Morris, D.W., Abramsky, Z., Fox, B., and Willig, M.R., Eds., Lubbock: Special Publ. Museum, Texas Technol. Univ., 1989, vol. 28, pp. 205-217.

Bar, Y., Abramsky, Z., and Gutterman, Y., Diet of gerbilline rodents in Israeli desert, J. Arid Environ., 1984, vol. 7, pp. 371-376.

Batzli, G.O. and Cole, F.R., Nutritional ecology of microtine rodents: digestibility of forage, J. Mammal., 1979, vol. 60 , pp. $740-750$.

Behmann, H., Vergleichend- und funktionell-anatomische Untersuchungen am Caecum und Colon myomorpher Nagetiere, Z. Wiss. Zool. Leipzig, 1973, vol. 186, nos. 3/4, pp. 173-296.

Brosh, A., Shkolnik, A., and Choshniak, I., Effects of infrequent drinking on the nitrogen metabolism of Bedouin goats maintained on different diets, J. Agric. Sci. Camb., 1987, vol. 109, pp. 165-169.

Carey, H.V. and Duddleston, K.N., Animal-microbial symbioses in changing environment, J. Therm. Biol., 2014, vol. 44 , pp. $78-84$.
Carmody, R.N., Gerber, G.K., Luevano, J.M.Cr., Gatti, D.M., Somes, L., Svenson, K.L., and Turnbaugh, P.G., Diet dominates host genotype in shaping the murine gut microbiota, Cell Host Microbe, 2015, vol. 17, pp. 72-84.

Daly, M. and Daly, S., Behavior of Psammomys obesus (Rodentia: Gerbillinae) in the Algerian Sahara, Ethology, 1975, vol. 37, pp. 298-321.

Degen, A.A., Ecophysiology of Small Desert Mammals, Berlin: Springer-Verlag, 1997.

Degen, A.A., Khokhlova, I.S., Kam, M., and Nagy, K.A., Body size, granivory and seasonal dietary shifts in desert gerbilline rodents, Funct. Ecol., 1997, vol. 11, pp. 53-59.

Degen, A.A., Kam, M., and Khokhlova, I.S., Fiber digestion and energy utilization of fat sand rats (Psammomys obesus) consuming the chenopod anabasis articulate, Physiol. Biochem. Zool., 2000, vol. 73, no. 5, pp. 574-580.

Fedorova, N.M. and Dubrovskii, V.Yu., The intensity of food consumption by the great gerbil (Rhombomys opimus), Zool. Zh., 1987, vol. 66, no. 10, pp. 1561-1565.

Foley, W.J. and Cork, S.G., Use of fibrous diets by small herbivores: how far the rule be "bent?," Trends Ecol. Evol., 1992, vol. 7, no. 5, pp. 159-162.

Fon, F.N. and Nsachlai, I.V., Seasonality of fibrolytic enzyme activity in herbivore microbial ecosystems, $A f r . J . A g$ ric. Res., 2012, vol. 11, pp. 13123-13130.

Freudenberger, D. and Hume, I., Effects of water restriction on digestive function in two macropodid marsupials from divergent habitats and the feral goat, J. Comp. Physiol., B: Biochem. Syst. Environ. Physiol., 1993, vol. 163, pp. 247257.

Friedrichsmeier, T., Rkward: Provides functions related to the RKWard GUI, 2018. https://rkward.kde.org.

Hammond, K.A. and Wunder, B.A., The role of diet quality and energy need in the nutritional ecology of a small herbivore, Microtus ochrogaster, Physiol. Zool., 1991, vol. 64, pp. 541-567.

Justice, K.E. and Smith, F.A., A model a dietary fiber utilization by small mammalian herbivores, with empirical results for Neotoma, Am. Nat., 1992, vol. 139, no. 2, pp. 398416.

Kennedy, P. and Hume, I., Recycling of urea nitrogen to the gut of the tammar wallaby (Macropus eugenii), Comp. Biochem. Physiol. A: Physiol., 1978, vol. 61, pp. 117-121.

Kohl, K.D. and Carey, H.V., A place for host-microbe symbiosis in the comparative physiologist's toolbox, J. Exp. Biol., 2016, vol. 219, pp. 3496-3504.

Kohl, K.D. and Dearing, M.D., Wild-caught rodents retain a majority of their natural gut microbiota upon entrance into captivity, Environ. Microbiol. Rep., 2014, vol. 6, pp. 191-195.

Kohl, K.D., Weiss, R.B., Dale, C., and Dearing, M.D., Diversity and novelty of the gut microbial community of an herbivorous rodent (Neotoma bryanti), Symbiosis, 2011, vol. 54, no. 1, pp. 47-54.

Kohl, K.D., Stengel, A., Samuni-Blank, M., and Dearing, M.D., Effect of anatomy and diet on gastrointestinal pH in rodents, J. Exp. Zool. A, 2013, pp. 1-5.

Kuznetsova, T.A., Kostina, N.V., Naumova, E.I., and Umarov, M.M., Microbial nitrogen fixation in the gastrointestinal tract of Kalmykia gerbils (M. tamariscinus and 
Meriones meridianus), Biol. Bull. (Moscow), 2010, vol. 37, no. 5, pp. 476-479.

Kuznetsova, T.A., Kam, M, Khokhlova, I.S., Kostina, N.V., Dobrovolskaya, T.G., Umarov, M.M., Shenbrot, G.I., and Krasnov, B.R., Desert gerbils affect bacterial composition of soil, Microbiol. Ecol., 2013, vol. 66, pp. 940-949.

Ley, R.E., Hamady, M., Lozupone, C., Tarnbauch, P.J., Ramey, R.R., Bircher, J.S., Schlegel, M.L., Tucker, T.A., Schrenzel, M.D., Knight, R., and Gordon, J.I., Evolution of mammals and their gut microbes, Science, 2008, vol. 320, pp. 1647-1651.

Muegge, B.D., Kusczinski, J., Knights, D., Clemente, J.C., Gonzalez, A., Fontana, L., Henrissat, B., Knight, R., and Gordon, J.I., Diet drives convergence in gut microbiome functions across mammalian phylogeny and within humans, Science, 2011, vol. 332, pp. 970-974.

Naumova, E.I., Funktsional'naya morfologiya pishchevaritel'noi sistemy gryzunov i zaitseobraznykh (Functional Morphology of the Digestive System of Rodents and Lagomorphs), Moscow: Nauka, 1981.

Naumova, E.I., Morphological and functional consequences of the coevolution of rodents with gastro-intestinal microbial endosymbionts, Belg. J. Zool., 1990, vol. 120, no. 2, pp. 195-204.

Naumova, E.I., Evolutionary pathways of using the plant food base by rodents, in Ekologiya v Rossii na rubezhe XXI veka (Ecology in Russia at the Turn of the 21st Century), Moscow: Nauchnyi Mir, 1999, pp. 181-212.

Naumova, E.I. and Zharova, G.K., Food specialization and features of gastric secretion in mammals, Dokl. Akad. Nauk SSSR, 1984, vol. 275, no. 5, pp. 1256-1260.

Naumova, E.I., Ushakova, N.A., Meshcherskii, I.G., Kostina, N.V., and Umarov, M.M., Nitrogen fixation: a new phenomenon in rodent nutrition, Biol. Bull. (Moscow), 2000, vol. 27, no. 3, pp. 272-274.

Naumova, E.I., Kuznetsova, T.A., Zharova, G.K., Chistova, T.Yu., and Varshavskii, A.A., Phytophagous mammals as donors of cellulose-decomposing microorganisms for cultivation for resource purposes, in Fundamental'nye osnovy upravleniya biologicheskimi resursami (Fundamental Bases of Biological Resource Management), Moscow: KMK, 2005, pp. 471-486.

Naumova, E.I., Zharova, G.K., and Chistova, T.Yu., Isolating structures of gerbils' digestive tract (Gerbillidae, Rhombomys, Meriones) and their functional significance, Biol. Bull. (Moscow), 2011, vol. 38, no. 4, pp. 379-385.

Naumova, E.I., Zharova, G.K., Chistova, T.Yu., and Kuznetsova, T.A., Functional and size characteristics of the digestive tract of the mole vole Ellobius talpinus, Biol. Bull. (Moscow), 2018, vol. 45, no. 4, pp. 388-393.

Naumova, E.I., Chistova, T.Yu., Zharova, G.K., Kam, M., Khokhlova, I.S., Krasnov, B.R., and Degen, A.A., Energy requirements, length of digestive tract compartments and body mass in six gerbilline rodents of the Negev Desert, Zoology, 2019, vol. 137, pp. 1-8.

Perrin, M.R. and Kokkinn, M.J., Comparative gastric anatomy of Cricetimys gambianus and Saccostomus campestris (Cricetomyinae) in relation to Mystromys albicaudatus (Cricetinae), S. Afr. J. Zool., 1985, vol. 21, pp. 202-210.
R Core Team, R: A Language and Environment for Statistical Computing, Vienna, Austria: R Foundation for Statistical Computing, 2019. https://www.R-project.org/.

Rabinovich, M.L. and Mel'nik, M.S., Advances in the study of cellulolytic enzymes and the mechanism of biodegradation of highly ordered forms of cellulose, Usp. Biol. Khim., 2000, vol. 40, pp. 205-266.

Rabinovich, M.L., Bolobova, A.V., and Kondrashchenko, V.I., Teoreticheskie osnovy biotekhnologii drevesnykh kompozitov (Theoretical Foundations of Biotechnology of Wood Composites), book 1: Drevesina i razrushayushchie ee griby (Wood and Fungi That Destroy It), Moscow: Nauka, 2001.

Sinitsyn, A.P., Chernoglazov, V.M., and Gusakov, A.V., Metody izucheniya i svoistva tsellyuloliticheskikh fermentov (Study Methods and Properties of Cellulolytic Enzymes), Itogi Nauki Tekhn., Ser. Biotekhnol., Moscow: VINITI, 1990, vol. 25.

Snipes, R.L., Anatomy of the caecum of the gerbil Meriones unguiculatus (Mammalia, Rodentia, Cricetidae), Zoomorphology, 1982, vol. 100, no. 3, pp. 189-202.

Stepan'kov, A.A., Kuznetsova, T.A., Umarov, M.M., Naumova, E.I., and Vecherskii, M.V., Urea recycling in muroid rodents, Biol. Bull. (Moscow), 2018, vol. 45, no. 1, pp. 69-72.

Tannock, G.W., Normal microbiota of the gastrointestinal tract of rodents, in Gastrointestinal Microbiology, vol. 1: Gastrointestinal Ecosystems and Fermentations, Mackie, R.I. and White, B.A., Eds., London: Chapman and Hall, 1997, pp. 187-215.

Tokuda, G., Lo, N., and Watanabe, H., Marked variations in patterns of cellulase activity against crystalline- vs. carboxymethyl-cellulose in the digestive systems of diverse, wood-feeding termites, Physiol. Entomol., 2005, vol. 30, no. 4, pp. 372-380.

Varshavskii, A.A., Naumova, E.I., and Tikhonov, I.A., Features of the functioning of cellulolytic symbionts in the proventriculus and cecum of gray voles (Microtus arvalis and M. rossiaemeridionalis), Zool. Zh., 2004, vol. 83, no. 11, pp. 1299-1304.

Vecherskii, M.V., Kuznetsova, T.A., and Stepan'kov, A.A., Activity of urealytic microorganisms in the gastrointestinal tract of the black grouse Lyrurus tetrix, Dokl. Biol. Sci., 2015, vol. 462, no. 3, pp. 131-133.

Vorontsov, N.N., Evolyutsiya pishchevaritel'noi sistemy mysheobraznykh gryzunov (Evolution of the Digestive System of Muroid Rodents), Novosibirsk: Nauka, 1967.

Vorontsov, N.N., Fauna SSSR (Fauna of the USSR), vol. 3: Mlekopitayushchie (Mammals), issue 3: Nizshie khomyakoobraznye (Cricetidae) mirovoi fauny (Lower Hamsters (Cricetidae) of the World Fauna), Pt. 1: Morfologiya $i$ ekologiya (Morphology and Ecology), Leningrad: Nauka, 1982.

Wickham, H., Ggplot2: Elegant Graphics for Data Analysis, New York: Springer-Verlag, 2016. https://ggplot2.tidyverse.org.

Wickham, H. and Henry, L., Tidyr: Tidy Messy Data, 2019. https://CRAN.R-project.org/package=tidyr.

Wickham, H., Francois, R., Henry, L., and Muller, K., Dplyr: A Grammar of Data Manipulation, 2019. https://CRAN. R-project.org/package=dplyr.

Translated by T. Kuznetsova 